\title{
Further studies on the effect of fat supplementation of concentrates fed to lactating dairy cows. 2 . Total digestion and energy utilization
}

Y. van der Honing ${ }^{1}$ S. Tamminga ${ }^{1}$, B. J. Wieman' ${ }^{1}$, A. Steg', B. van Donselaar' and L. G. M. van Gils ${ }^{2}$

1 Institute for Livestock Feeding and Nutrition Research, Lelystad, Netherlands

${ }^{2}$ Institute for Scientific Research in the field of Animal Nutrition, Trouw \& Co International, Putten, Netherlands

Accepted: 14 September 1982

Key-words: energy utilization, balance trials, dairy cow, wether, digestibility, fat-enriched concentrates

\section{Summary}

Dairy concentrates were supplemented with 7 or $12 \%$ of a mixture containing $90 \%$ beef tallow and $10 \%$ palm kernel oil. These concentrates were fed to dairy cows included in diets consisting of $30 \%$ long hay and $70 \%$ concentrates. Digestibility and energy utilization by cows at feeding level over 3 times maintenance were studied. Digestibility was also studied in wether sheep fed at maintenance.

Fat supplementation did not significantly depress digestion of one of the dietary components, neither in dairy cows nor in wether sheep. Methane losses tended to decrease with an increasing level of supplemented fat, both in dairy cows and in sheep.

Energy utilization in dairy cows was similar as predicted from the Dutch energy feed evaluation system.

\section{Introduction}

In recent years various reports were published on the utilization of fats by dairy cows (Palmquist, 1978, 1980, 1981; Rohr et al., 1978; Storry, 1981; van der Honing et al., 1981). Because of its high energy content and high digestibility, fat may be a useful source of energy to increase the energy density of the diet if the ingestion of energy is restricted by a limited dry matter intake, which is often the case in early lactation. The inclusion of fairly large amounts of fat in the diets for dairy cows may cause negative aspects with regard to the digestion of structural carbohydrates. Reports on this aspect are however conflicting (Dijkstra, 1969; Rohr et al., 1978; Palmquist, 1978; van der Honing et al., 1981). Besides, there 
are some findings which suggest that the inclusion of fats in the diet shifts the site of digestion from the forestomachs towards the intestines (Knight et al., 1978), and that fat influences rumen fermentation patterns (Kowalczyk et al., 1977; Knight et al., 1978).

Little is known on the energetic efficiency with which fats are being utilized. From the available data it seems that energy in dietary fat is being utilized with at least the same efficiency as energy in other dietary components (van der Honing et al., 1981), but the amounts of fat ingested by the animals in these experiments were comparatively small, which makes it difficult to predict the partial efficiency with which fat is utlized. To study some of the questions mentioned above, it was decided to perform a number of experiments with a larger proportion of fat in the diets. The experiments were done with lactating dairy cows fitted with either a rumen fistula only or equipped with a rumen fistula and re-entrant cannulae in the small intestine. These animals were fed diets of which two thirds of the dry matter intake was from concentrates which contained up to $12 \%$ of supplemented fat. Digestion, site of digestion, rumen fermentation patterns and utilization of energy were studied. This paper reports on total apparent digestion of such diets and on energy utilization. In a subsequent paper (Tamminga et al., 1983) the effect of dietary fat on rumen fermentation characteristics and on site of digestion will be reported.

\section{Materials and methods}

Energy balance experiments were performed with four lactating dairy cows; two of them were fitted with a rumen fistula only, the other two were also equipped with re-entrant cannulae at the beginning of the small intestine. The animals were kept individually and fed twice daily with $7 \mathrm{~kg}$ of long hay and $12-14 \mathrm{~kg}$ of concentrates (animals with a rumen fistula only) or with $4-5 \mathrm{~kg}$ of long hay and $8-10 \mathrm{~kg}$ of concentrates (animals with a rumen fistula and duodenal re-entrant cannulae). The cows were 2 to 9 months in lactation and produced $8-25 \mathrm{~kg}$ of milk. The animals with a rumen fistula only received three treatments, concentrates supplemented with $7 \%$ of fat (treatment C7), concentrates supplemented with $12 \%$ of fat (treatment $\mathrm{C12}$ ) and concentrates supplemented with $12 \%$ of fat absorbed on a carrier of Palabora vermiculite (treatment C12C). Fat was adsorbed on the carrier of vermiculite in a premix. This premix was subsequently mixed with the other ingredients and pelleted. Of these three treatments the animals also equipped with duodenal re-entrant cannulae received treatment $\mathrm{C} 12$ and $\mathrm{C} 12 \mathrm{C}$ only.

Feeding was twice daily: at $6 \mathrm{~h} 00$ and $15 \mathrm{~h} 30$ hay was offered whereas concentrates were offered one hour later.

In addition to the experiments with dairy cows, digestibility $(d)$ and metabolizable energy (ME) of hay and of the concentrates were determined in 4 mature wether sheep fed near maintenance. In addition to the three concentrate mixtures used in the experiments with dairy cows, a concentrate without supplemented fat was also fed to the sheep (treatment $\mathrm{CO}$ ). 
Table 1. Composition of the concentrates $(\mathrm{g} / \mathrm{kg})$.

\begin{tabular}{lcccc}
\hline Feedstuff & $\mathrm{C}$ & $\mathrm{C} 7$ & $\mathrm{C} 12$ & $\mathrm{C} 12 \mathrm{C}$ \\
Soya bean meal & 296 & 274 & 260 & 248 \\
Maize gluten feed & 261 & 242 & 230 & 219 \\
Sugar-beet pulp & 153 & 142 & 135 & 128 \\
Citrus pulp & 153 & 142 & 135 & 128 \\
Tapioca & 45 & 42 & 40 & 38 \\
Molasses & 23 & 21 & 20 & 19 \\
Beef tallow & - & 68 & 110 & 105 \\
Palm kernel oil & - & 5 & 10 & 10 \\
Minerals/vitamins & 28 & 26 & 25 & 24 \\
MgO & 6 & 5 & 5 & 5 \\
Limestone & 6 & 5 & 5 & 5 \\
Durabond & 28 & 26 & 25 & 24 \\
Vermiculite & - & - & - & 48 \\
& & & & \\
Indrymatter & & 226 & 218 & 199 \\
Crude protein $(\mathrm{g} / \mathrm{kg})$ & 239 & 19.8 & 20.5 & 19.3 \\
Gross energy $(\mathrm{MJ} / \mathrm{kg})$ & 17.6 & & & \\
\hline
\end{tabular}

The composition of the concentrate mixtures is given in Table 1 . Because the fat was added to the control mixtures rather than replacing one or more ingredients, the protein to energy ratio differed between diets. However, even the lowest ratio yielded enough protein to meet the requirements. Experimental procedures, sampling and analytical procedures were as described by van der Honing et al. (1981).

\section{Results and discussion}

\section{Digestibility}

Table 2 shows the digestibility of hay and concentrates (the latter by difference) obtained from wether sheep fed with $1100 \mathrm{~g}$ hay only or with $300 \mathrm{~g}$ hay and $800 \mathrm{~g}$

Table 2. Coefficients of digestibility of hay and concentrates fed to 4 wether sheep at about their maintenance level of feeding.

\begin{tabular}{|c|c|c|c|c|c|c|}
\hline \multirow{2}{*}{$\begin{array}{l}\text { Ration } \\
\text { component }\end{array}$} & \multicolumn{6}{|c|}{ Coefficient of digestibility $(\%)$ of } \\
\hline & $\mathrm{OM}$ & $\mathrm{XP}$ & $\mathrm{XL}^{2}$ & $\mathrm{XF}$ & $\mathrm{XX}$ & energy \\
\hline Hay & 74.3 & 75.0 & 51.0 & 75.2 & 75.0 & $70.8 \pm 3.0$ \\
\hline $\mathrm{CO}$ & 84.0 & 84.5 & 67.5 & 75.3 & 85.8 & $83.1 \pm 1.6$ \\
\hline $\mathrm{C7}$ & 84.0 & 83.3 & 90.7 & 71.5 & 84.8 & $84.3 \pm 1.4$ \\
\hline $\mathrm{C} 12$ & 82.5 & 83.3 & 91.6 & 64.0 & 82.2 & $84.2 \pm 1.3$ \\
\hline $\mathrm{C} 12 \mathrm{C}$ & 83.2 & 82.6 & 90.0 & 65.2 & 84.4 & $83.0 \pm 1.8$ \\
\hline
\end{tabular}

$\mathrm{XP}=$ crude protein: $\mathrm{XL}=$ crude fat; $\mathrm{XF}=$ crude fibre; $\mathrm{XX}=\mathrm{N}$-free extract

2 Analysis based on hexane extraction preceded by hydrolysis with $\mathrm{HCl}$. 
Table 3. Dry matter intake $\left(I_{\mathrm{T}}\right)$ of the different diets by dairy cows and its chemical composition (g/kg DM).

\begin{tabular}{llllllll}
\hline Diet & $\begin{array}{l}\text { Number } \\
\text { of } \\
\text { animals }\end{array}$ & $\begin{array}{l}\mathrm{I}_{\mathrm{T}} \\
(\mathrm{kg})\end{array}$ & $\begin{array}{l}\mathrm{XP} \\
(\mathrm{g} / \mathrm{kg})\end{array}$ & $\begin{array}{l}\mathrm{XL} \\
(\mathrm{g} / \mathrm{kg})\end{array}$ & $\begin{array}{l}\mathrm{XF} \\
(\mathrm{g} / \mathrm{kg})\end{array}$ & $\begin{array}{l}\mathrm{XX} \\
(\mathrm{g} / \mathrm{kg})\end{array}$ & $\begin{array}{l}\text { Energy } \\
(\mathrm{MJ} / \mathrm{kg})\end{array}$ \\
$\mathrm{C7}$ & $2-$ & 17.6 & 222 & 84 & 146 & 466 & 19.3 \\
$\mathrm{C} 12$ & $2-$ & 17.5 & 213 & 114 & 139 & 452 & 19.8 \\
C12 & $2+$ & 12.1 & 217 & 112 & 138 & 450 & 19.8 \\
C12C & $2-$ & 18.0 & 199 & 102 & 140 & 447 & 18.9 \\
C12C & $2+$ & 12.2 & 202 & 107 & 138 & 442 & 19.0 \\
\hline
\end{tabular}

1 - animals with rumen fistula only; + animals with rumen fistula and duodenal re-entrant cannulae.

of one of the concentrates $\mathrm{C} 0, \mathrm{C} 7, \mathrm{C} 12$ or $\mathrm{C} 12 \mathrm{C}$. The addition of fat tended to affect the crude fibre digestibility negatively, but because of the rather large standard error the differences were not statistically significant. Digestibility of crude fat increased with the addition of fat, because the digestibility of the added fat was very high and also because the fraction of endogenous fat excreted in the faeces became a smaller proportion of the fat ingested. These results are in agreement with results obtained earlier (van der Honing et al., 1981), but are conflicting with various other results (Dijkstra, 1969; Buysse, 1962; Cottijn et al., 1971; Devendra \& Lewis, 1974).

In Table 3 the average dry matter intake $\left(I_{T}\right)$ by the cows as well as the chemical compositon of the ingested dry matter is given. The crude fibre content of the diets was below $15 \%$ which is below normally recommended minimum levels, but this did not cause major intake problems as shown by the fairly high feed intake obtained with the animals equipped with a rumen fistula only.

The digestibility coefficients of the rations ingested by the dairy cows are shown in Table 4. No significant differences in the digestibility of organic matter $(\mathrm{OM})$, crude protein (XP), crude fat (XL), crude fibre (XF), N-free extracts (XX) or energy were observed. The absence of a decreased crude fibre digestibility with increasing a mounts of fat is difficult to explain. One might assume that due to the feeding of a concentrates-rich diet $d_{\mathrm{XF}}$ was already reduced, but because the $d_{\mathrm{XF}}$ figures are rather high $(75-78 \%)$, this explanation does not seem very likely. Besides, the ratio of long roughage to concentrates was higher in the cows than in the sheep. whereas in the sheep the $d_{\mathrm{xF}}$ tended tot be negatively influenced by the addition of fat, but not in the cows. It seems more likely to assume that during mixing or compression to pellets, the supplemented fat became absorbed to one or more of the ingredients of the concentrates which caused a delay in the interfering with the microbial degradation of other dietary components, the cell wall constituents of the roughage part of the diet in particular. Because of the much higher level of feed intake in the cows as compared with the sheep, causing a shorter retention time in the forestomachs the cows could take advantage of this situation, but not the sheep.

The effect of an increased level of feeding on digestibility, assuming an equal 
Table 4. Digestibility coefficients $(d)$ of the ratios ingested by dairy cows and an estimation of the depression of digestibility $(\Delta)$ in units of $d$ due to increased level of feeding (FL), assuming the same digestibility at maintenance in cows and sheep.

\begin{tabular}{|c|c|c|c|c|c|c|c|c|}
\hline Ration' & & $\mathrm{OM}$ & XP & $\mathrm{XL}^{2}$ & $X F$ & $\mathrm{XX}$ & Energy & $\mathrm{FL}^{3}$ \\
\hline \multirow[t]{2}{*}{ C7- } & d & 75.6 & 68.9 & 74.8 & 72.3 & 80.0 & 73.4 & 3.72 \\
\hline & $\Delta$ & 5.1 & 11.9 & 11.2 & 1.5 & 1.9 & 6.5 & \\
\hline \multirow[t]{2}{*}{$\mathrm{C} 12-$} & $d$ & 75.0 & 70.8 & 71.2 & 70.4 & 79.2 & 72.4 & 3.64 \\
\hline & $\triangle$ & 4.8 & 10.0 & 16.9 & 0.7 & 0.7 & 7.7 & \\
\hline \multirow[t]{2}{*}{$\mathrm{Cl} 2+$} & d & 75.6 & 73.5 & 72.7 & 69.5 & 79.3 & 73.2 & 2.68 \\
\hline & $\Delta$ & 4.3 & 7.4 & 15.2 & 1.6 & 0.8 & 7.0 & \\
\hline \multirow[t]{2}{*}{$\mathrm{C} 12 \mathrm{C}-$} & $\mathrm{d}$ & 75.6 & 70.6 & 74.1 & 68.7 & 80.2 & 73.0 & 3.60 \\
\hline & $\triangle$ & 4.6 & 9.4 & 12.0 & 2.9 & 1.2 & 5.9 & \\
\hline \multirow[t]{2}{*}{$\mathrm{C} 12 \mathrm{C}+$} & $\mathrm{d}$ & 76.2 & 72.1 & 71.7 & 66.4 & 82.2 & 73.4 & 2.64 \\
\hline & $\triangle$ & 4.0 & 8.1 & 14.5 & 5.1 & -0.7 & 5.8 & \\
\hline
\end{tabular}

1 - animals with rumen fistula only; + animals with rumen fistula and duodenal re-entrant cannulae.

2 Analysis based on hexane extraction preceded by hydrolysis with $\mathrm{HCl}$.

${ }^{3} \mathrm{FL}=$ feeding level (multiple of maintenance energy requirement).

digestibility in cows and sheep fed at maintenance, is also shown in Table 4. If expressed per unit of increased feeding level above maintenance, the reduction in apparent digestibility varies between 0.2 and 5.5 percentage units with highest reductions for $d_{\mathrm{XL}}, d_{\mathrm{XP}}$, and $d_{\mathrm{E}}$ and lowest for $d_{\mathrm{XF}}$ and $d_{\mathrm{XX}}$. The high reduction for $d_{\mathrm{XL}}$ is difficult to explain. In earlier experiments (van der Honing et al., 1981) concentrates supplemented with $7 \%$ fat were also fed to dairy cows. In these experiments reductions of $d_{\mathrm{xl}}$, due to feeding level were much smaller and averaged 2.0 units. In those experiments as well as in the experiments reported here, good quality hay was fed with an almost similar digestibility. Composition of the concentrates fed in the different experiments only differed in soya bean meal, coconut cake and the inclusion of durabond (calciumlignosulphonate) in the experiments reported here. With respect to the animals the experiments reported here were performed with surgically modified animals, either equipped with a rumen fistula or equipped with a rumen fistula and duodenal re-entrant cannulae. In a comparison between normal animals and animals with re-entrant cannulae the results of 36 digestion studies in normal cows were compared with the results of 32 digestion studies in cows equipped with re-entrant cannulae (Zijlstra, 1977). It was found that $d_{\mathrm{XL}}$ obtained with cows equipped with re-entrant cannulae was some $10 \%$ lower than $d_{\mathrm{XL}}$ obtained in normal cows. In the experiments reported here, the reduction in $d_{\mathrm{XL}}$, if expressed per increased level of feeding, was 5.5 units on average, whereas in the animals with a rumen fistula only the reduction in $d_{\mathrm{xL}}$ was 3.7 units. Feeding the $\mathrm{C} 12$ and $\mathrm{C} 12 \mathrm{C}$ concentrates showed the highest depression in $d_{\mathrm{xL}}$, if expressed per unit of maintenance. In this case the fat supply to the small intestine may have exceeded its capacity of fat absorption. It has been shown (Wrenn et al., 1976; Tamminga et al., 1976; Palmquist \& Conrad, 1978) that there is an upper limit in the amount of fat which can be absorbed by ruminants. For Friesian cows this limit was suggested 
to lie between 1215 and $2180 \mathrm{~g} /$ day (Storry, 1981). Fat intake in our experiments ranged between 1300 and $2000 \mathrm{~g} /$ day and falls within that range. The observed high depression in $d_{\mathrm{XL}}$ is also reflected in a somewhat higher depression in $d_{\mathrm{E}}$ as compared with the depression in $d_{\mathrm{OM}}$. The high reduction in $d_{\mathrm{XP}}$ confirmed earlier findings (van der Honing et al., 1981).

The small reductions found for $d_{\mathrm{XF}}$ may at least partly be the result of the lower $d_{\mathrm{XF}}$ found with wether sheep fed at maintenance level, because these lower figures were used to estimate the figures for cows. It may show that in these fatenriched diets the assumptions of equal digestion capacity of sheep and cattle at maintenance level of feeding seems disputable.

The introduction of a carrier of vermiculite on which the fat was absorbed before being included in the concentrate (C12C), did not have much effect on the digestibilities of the other ingredients, neither in wethers, nor in cows. Adsorbing the fat on a carrier was thought to prevent it from interfering with the microbial degradation of other ingredients, but the results show that without a carrier digestion of other ingredients was hardly influenced by the inclusion of fat in the diet, so an effect of the use of a carrier could hardly be expected. The possibility existed on the other hand that adsorbing the fat on a carrier might have a negative influence on $d_{\mathrm{xL}}$, but no indication for this was found.

\section{Metabolizability and utilization of metabolizable energy}

Table 5 shows the energy lost in urine or as methane by wethers and dairy cows, as well as metabolizability of their diets.

Both in cows and in sheep methane losses decreased from diet $\mathrm{C} 7$ to $\mathrm{C} 12$, but the effect tended to be lower from $\mathrm{C} 7$ to $\mathrm{C} 12 \mathrm{C}$. In sheep methane losses also decreased from diet $\mathrm{C} 0$ to $\mathrm{C} 7$. This was also found in sheep and cows in previous

Table 5. Daily energy loss in methane and urine and metabolizability $\left(q=100 \mathrm{ME} / \mathrm{I}_{\mathrm{E}}\right)$.

\begin{tabular}{|c|c|c|c|c|c|c|c|}
\hline \multirow[t]{2}{*}{ Animals } & \multirow[t]{2}{*}{$\mathrm{n}$} & \multirow[t]{2}{*}{ Ration $^{1}$} & \multicolumn{2}{|c|}{ Methane energy } & \multicolumn{2}{|c|}{ Urine energy } & \multirow[t]{2}{*}{$\mathrm{q}$} \\
\hline & & & $\mathrm{MJ} / \mathrm{day}$ & $\%$ of $\mathrm{l}_{\mathrm{E}}$ & $\mathrm{MJ} /$ day & $\%$ of $\mathrm{I}_{\mathrm{E}}$ & \\
\hline Cows & 2 & $\mathrm{C} 7-$ & 17.7 & 5.23 & 15.6 & 4.59 & 63.6 \\
\hline Cows & 2 & $\mathrm{Cl} 2-$ & 15.6 & 4.51 & 15.2 & 4.41 & 63.5 \\
\hline Cows & 2 & $\mathrm{Cl} 2+$ & 11.7 & 4.87 & 10.5 & 4.35 & 64.0 \\
\hline Cows & 2 & $\mathrm{Cl} 2 \mathrm{C}-$ & 16.7 & 4.97 & 14.4 & 4.29 & 63.8 \\
\hline Cows & 2 & $\mathrm{Cl} 2 \mathrm{C}+$ & 12.6 & 5.46 & 9.9 & 4.31 & 63.6 \\
\hline Sheep & 2 & Hay & 1.30 & 7.44 & 1.10 & 6.27 & 57.1 \\
\hline Sheep & 4 & $\mathrm{CO}$ & 1.50 & $8.70^{2}$ & 1.17 & 7.04 & 63.9 \\
\hline Sheep & 4 & $\mathrm{C} 7$ & 1.24 & 6.57 & 1.27 & 6.67 & 67.5 \\
\hline Sheep & 4 & $\mathrm{C} 12$ & 0.97 & 4.91 & 1.20 & 6.17 & 69.9 \\
\hline Sheep & 4 & $\mathrm{C} 12 \mathrm{C}$ & 1.05 & 5.53 & 1.03 & $5.50^{3}$ & 68.6 \\
\hline
\end{tabular}

1 - animals with rumen fistula only; + animals with rumen fistula and duodenal re-entrant cannulae.

2 Average of 2 animals.

3 Average of 3 animals. 
Table 6. Daily intake of metabolizable energy (ME) and energy produced as milk (LE) and retained (RE) by dairy cows. Assumed net energy for maintenance $\left(\mathrm{NE}_{\mathrm{m}}\right)=0.293 \mathrm{MJ} / \mathrm{kg}^{3 / 4}$ (van Es, 1978).

\begin{tabular}{llllll}
\hline Ration' & $\begin{array}{l}\mathrm{ME} \\
(\mathrm{MJ})\end{array}$ & $\begin{array}{l}\mathrm{LE} \\
(\mathrm{MJ})\end{array}$ & $\begin{array}{l}\mathrm{RE} \\
(\mathrm{MJ})\end{array}$ & $\begin{array}{l}\mathrm{NE}_{\mathrm{m}} \\
(\mathrm{MJ})\end{array}$ & $\mathrm{k}=\left(\mathrm{LE}+\mathrm{RE}+\mathrm{NE}_{\mathrm{m}}\right) / \mathrm{ME}$ \\
$\mathrm{C} 7-$ & 215.8 & 71.2 & 25.6 & 34.9 & 0.610 \\
$\mathrm{C} 12-$ & 220.3 & 61.8 & 37.5 & 36.3 & 0.616 \\
$\mathrm{C} 12+$ & 152.5 & 39.8 & 18.7 & 34.3 & 0.610 \\
$\mathrm{C} 12 \mathrm{C}-$ & 214.9 & 71.5 & 27.0 & 35.7 & 0.625 \\
$\mathrm{C} 12 \mathrm{C}+$ & 146.8 & 37.6 & 20.4 & 33.2 & 0.623 \\
\hline
\end{tabular}

1 - animals with rumen fistula only; + animals with rumen fistula and duodenal re-entrant cannulae.

trials (van der Honing et al., 1981).

Urinary energy losses in cattle were not different between diets.

The inclusion of $7 \%$ fat increased metabolizability $(q)$ of the sheep diets, but a higher percentage of fat failed to improve $q$ any further. The $q$ of the cattle diets were not significantly different. The latter effect on $q$ is much less than the effect by using 5 or $7 \%$ of supplemented fat in the previous trials. Although in the present experiment highly digestible fat was supplemented, which moreover caused slightly lower methane losses by cattle and sheep, it is somewhat disappointing to observe equal $q$ for all cattle diets. Obviously the positive influence of fat on $q$ must be compensated for by a negative effect on digestion of other constituents, although significant effects could not be proven.

The energy produced as milk or retained as body reserves is shown in Table 6. All cows were in positive energy balance. Milk yield of the two cows with only rumen fistula was between 19 and $26 \mathrm{~kg}$ / day and of the other two cows between 6.5 and 20 , mainly due to the later stage of lactation.

To calculate the overall efficiency $(k)$ of utilization of ME by dairy cows it is necessary to assume a value for net energy used for maintenance. Assuming this value to be $0.293 \mathrm{MJ}$ per $\mathrm{kg}^{3 / 4}$ (metabolic body weight) as proposed by van Es (1978) resulted in the $k$ values presented in Table 6.

The high level of feeding compared to the needs for maintenance and actual milk production resulted in a substantial storage of energy as body reserves. So it seems likely that part of the absorbed fatty acids are used for body fat deposition, which is a very efficient process from a biochemical point of view.

In biochemical terms the utilization of mobilized body fat for milk fat synthesis is also said to be efficient and to vary between 71 and $98 \%$ (Kronfeld, 1976). Estimates of the efficiency of utilization of mobilized body tissue for milk production from energy balance experiments vary between $80-85 \%$, although the precision is not very good (van Es, 1969; Moe et al., 1972; Schiemann et al., 1974). Although the efficiencies presented by Kronfeld (1976) are maximum values, neglecting turnover etc., and the efficiency of utilization of ME computed from energy balance trials is substantially lower it is still difficult to believe that 
the efficiency of utilization of ME from supplemented high-quality fat is as low as $60 \%$.

The $k$ in Table 6 can be compared with the value $(\hat{K})$ expected from the equation describing the utilization of ME by dairy cows in the Dutch feed evaluation system (van Es, 1978):

$$
\hat{k}=0.6+0.0024(q-57)
$$

The average $\hat{k}$ of all 10 energy balance trials with dairy cows was 0.617 , which did not differ from the calculated $k$ value of 0.616 . Comparison of $k$ and $\hat{k}$ on a within-cow basis resulted in a non-significant difference between $\mathrm{C} 7$ and $\mathrm{C} 12$ or $\mathrm{C} 12 \mathrm{C}$ (only 2 cows), but a slightly better $k$ for $\mathrm{C} 12 \mathrm{C}$ compared to $\mathrm{C} 12$ was found $(\mathrm{P} \leqslant 0.10)$.

Although difficult and not very precise, it was tried to estimate the efficiency of utilization of ME from the supplemented fat $(k$-fat $)$. It was assumed that supplemented fat contained 0.9 times its gross energy $(39.7 \mathrm{~kJ} / \mathrm{g})$ as ME. From the sheep trials an estimated digestibility of $90 \%$ seems acceptable, whereas no losses in methane and as urine were assumed. By subtracting ME as fat from total $M E$ in the diet the ME of the non-fat residual was obtained and in a similar way gross energy of the non-fat residual of the cow diets. So $q$ was calculated and by using the above equation also an estimate of $\hat{k}$ of the non-fat residual, which could be used to estimate the net energy from this non-fat part. By subtracting the latter from total net energy an estimate of the net energy from the fat supplement was obtained and an estimated $k$-fat could be calculated. These $k$-fat values, quite variable between individual cows, due to all errors cumulating in this value, averaged $0.663 \pm 0.028$. Assuming a digestibility of $75 \%$ for the fat-supplement changed this value to $0.645 \pm 0.034$. Although the values on diet $\mathrm{C} 12 \mathrm{C}$ tended to be higher, it will be clear that no statistical significance could be proven.

From this it will be clear that the efficiency of utilisation of the fat in these fatenriched diets is much lower than was to be expected. The reason for this apparent discrepancy is not clear. Kronfeld (1976) assumed that an optimal digested fatty acid to non-fatty acid ME ratio to reach maximal efficiency of milk production would be about $16 \%$. The ratio in diets fed in the experiments reported here were much higher and varied from 20 to $27 \%$, which may explain the low efficiency of utilization. Reduced efficiencies of utilization of energy with high fat diets were also observed by Brumby et al. (1978).

Our results show that $\mathrm{ME}$ from supplemented fat is utilized as efficiently as ME from normal diets, but leaves the question how this low efficiency should be explained in view of the higher expected values from biochemical point of view.

Irrespective of treatments the milk fat content tended to show an initial increase followed by a decrease with time in the course of the experiments in all cows. This decrease, which tended to overrule the possible effects of the presence or absence of a carrier, was also observed in other experiments (Rijpkema \& de Visser, 1982; de Visser et al., 1982) and was thought to result from an in- 
fluence on the animals endocrine balance. The nature of this influence is not yet clear.

\section{Conclusions}

Supplementing the concentrates mixture (by adding from 7 to $12 \%$ tallow) in a low-forage diet, fed to dairy cows, improved the digestibility of lipids in mature wethers fed at maintenance, but not in dairy cows fed two to three times maintenance. The apparent digestibility of other dietary ingredients was hardly affected. Although slightly lower methane losses with increased fat supplementation were found, no significantly different metabolizability was observed. Utilization of metabolizable energy could well be described by the equation of van Es (1978) in the Dutch feed evaluation system; this included a rather low efficiency of utilization of ME from supplemented fat compared to values reported in the literature from biochemical knowledge and from utilization of fat from mobilized body tissues. The reason for this discrepancy needs further research.

\section{References}

Buysse, F. X., 1962. De invloed van grotere vethoeveelheden op de verteerbaarheid van de voedende bestanddelen in 't bijzonder van de ruwe celstof, bij herkauwers (schapen). Landbouwtijdschrift 15: 371-380.

Cottyn, B. G., F. X. Buysse \& Ch. V. Boucqué, 1971. The effect of linseed oil fatty acids on digestibility and rumen fermentation. Z. Tierphysiol. Tierernähr. Futtermittelkde 27: 252-259.

Devendra, C.\& D. Lewis, 1974. The interaction between dietary lipids and fibre in sheep. Malaysian agric. Res. 3: 163-176.

Dijkstra, N. D., 1969. Influence of supplemented animal fats upon digestibility of ration components by ruminants. Neth. J. agric. Sci. 17:27-40.

Es, A. J. H. van, 1969. The efficiency of the utilization of the metabolizable energy by lactating cows fed concentrates and either hay, silage or hay and hay or straw pellets. Proc. 3rd gen. Meet. Eur. Grassld Fedn: 275-281.

Es, A. J. H. van, 1978. Feed evaluation for ruminants. 1. The system in use from May 1977 onwards in The Netherlands. Livestock Prod. Sci. 5: 331-345.

Es, A. J. H. van \& Y. van der Honing. 1979. Energy utilization. In: W. H. Broster \& H. Swan (Eds.), Feeding strategy of the high producing dairy cow. Granada Publishing, London, pp. 68-89.

Honing, Y. van der, B. J. Wieman, A. Steg \& B. van Donselaar, 1981. The effect of fat supplementation of concentrates on digestion and utilisation of energy by productive dairy cows. Neth. J. agric. Sci. 29: 79-92.

Knight, R., J. D. Sutton, A. B. McAllan \& R. H. Smith, 1978. The effect of dietary lipid supplementation on digestion and synthesis in the stomach of sheep. Proc. Nutr. Soc.: 37-14A.

Kowalczyk, J., E. R. Ørskov, J. J. Robinson \& C. S. Stewart, 1979. Effect of fat supplementation on voluntary food intake and rumen metabolism in sheep. Br. J. Nutr. 37: 251-257.

Kronfeld, D. S., 1976. The potential importance of the proportions of glucogenic, lipogenic and aminogenic nutrients in regard to the health and productivity of dairy cows. Fortschr. Tierphysiol. Tierernähr. 7: 5-26.

Moe. P. W., H. F. Tyrrell \& W. P. Flatt. 1971. Energetics of body tissue mobilization. J. Dairy Sci. 54: 548-553.

Moe, P. W., W. P. Flatt \& H. F. Tyrrell, 1972. Net energy value of feeds for lactation. J. Dairy Sci. 55: $945-958$.

Palmquist, D. L., 1978. High fat dairy rations. Proc. Cornell Nutr. Conf. Feed Manuf: 112-117.

Neth. J. agric. Sci. 31 (1983) 
Palmquist, D. L. 1981. Fat as an energy source in lactation diets. Proc. Georgia Nutr. Conf.: 148-160.

Palmquist, D. L. \& H. R. Conrad, 1978. High fat rations for dairy cows. Effects on feed intake, milk and fat production and plasma metabolites. J. Dairy Sci. 61: 890-901.

Palmquist. D. L. \& T. C. Jenkins, 1980. Fat in lactation rations: Review. J. Dairy Sci. 63: 1-14.

Rohr. K.. R. Daenicke \& H. J. Oslage, 1978. Untersuchungen über den Einfluss verschiedener Fettbeimischungen zum Futter auf Stoffwechsel und Leistung von Milchkühen. Landbauforschung Völkenrode 28: 139-150.

Schiemann, R., G. Henseler, W. Jentsch \& H. Wittenburg, 1974. Die Verwertung der Futterenergie für die Milchproduktion. 8. Mitt. Arch. Tierernähr. 24: 105-137.

Storry, J. E., 1981. The effect of dietary fat on milk composition. In: W. Haresign \& D. Lewis (Ed.). Recent advances in animal nutrition. Butterworth, London.

Tamminga, S., A. Steg-Beers, W. van Hoven \& H. T. Badings (1976). Production of milk with a high content of polyunsaturated fatty acids. 1. Experiments in relation to the efficiency of production. Neth. Milk Dairy J. 30: 106-117.

Tamminga, S., A. M. van Vuuren, C. J. van der Koelen \& H. M. M. Khattab, 1983. Further studies on the effect of fat supplementation of concentrates fed to lactating dairy cows. 3 . Rumen fermentation characteristics and site of digestion. (In press.)

Wrenn. T. R., J. Bitman, R. A. Waterman, J. R. Weyant, D. L. Wood. L. L. Strozinski \& N. W. Hooven Jr. 1976. Feeding protected and unprotected tallow to lactating cows. J. Dairy Sci. 61: 49-58.

Zijlstra. J.. 1977. De invloed van het meten van darmdoorstroming op ligtijden en vertering bij koeien. IVVO Documentatierapport No 30. 